\title{
IT'S A QUESTION OF MARKET ACCESS
}

\author{
By Kyle Bagwell, Petros C. Mavroidis, and Robert W. Staiger*
}

\section{A LAW AND ECONOMICS APPROACH TO THE OPTIMAL WTO MANDATE}

\section{The Economic Rationale for Trade Agreements}

In this paper, we argue that market access issues associated with the question of the optimal mandate of the World Trade Organization should be separated from nonmarket access issues. We identify race-to-the-bottom and regulatory-chill concerns as market access issues and suggest that the WTO should address these concerns. We then describe ways that WTO principles and procedures might be augmented to do so. As for nonmarket access issues, we argue that as a general matter these are best handled outside the WTO, and that, while implicit links might be encouraged, explicit links between the WTO and other labor and environmental organizations should not as a general matter be forged. We view this as a measured approach to labor and the environment within the WTO.

To provide the foundation for our proposals, we first present an economic framework. ${ }^{1}$ Suppose there are two countries, country $A$ and country $B$, whose respective governments are government $A$ and government $B$. Country $A$ exports good $\alpha$ to country $B$, and country $B$ exports good $\beta$ to country $A$. The two governments each choose import tariffs, and they may also select export policies and domestic policies (such as labor and environmental standards). For now, we focus on the selection of import tariffs. Given that this world has no trade agreement, each government selects its import tariff in a unilateral fashion (i.e., to best achieve its own policy objectives).

Consider now the trade-offs that government $A$ perceives when it sets its import tariff on $\operatorname{good} \beta$. A higher import tariff leads to a higher price of good $\beta$ in country $A$. As a consequence, there are winners and losers in country $A$ : the higher price benefits its importcompeting firms and hurts its consumers. Of course, depending on the level of the tariff, an increase may also generate greater tariff revenue for country $A$, and these proceeds may be distributed to consumers so as to ease (or even reverse) the harm to them. By assessing these various effects and weighing how they contribute to or detract from its objectives, government $A$ determines the unilateral tariff that best achieves its objectives. In similar fashion, government $B$ determines its preferred unilateral tariff on good $\alpha$.

Government $A$ 's calculus of winners and losers neglects an important party: the exporters from country $B$. Exporting firms would naturally be expected to bear some of the incidence of a tax. Put differently, if the import tariff on $\operatorname{good} \beta$ is raised by a dollar, then the price of good $\beta$ in country $A$ is likely to rise by something short of a dollar. Some of the tariff hike

\footnotetext{
* Kyle Bagwell, Kelvin J. Lancaster Professor of Economic Theory, Department of Economics and Graduate School of Business, Columbia University; Petros C. Mavroidis, Faculty of Law, University of Neuchâtel; and Robert W. Staiger, Department of Economics, University of Wisconsin, Madison. We would like to thank Henrik Horn af Rantzien for very helpful discussions.

${ }^{1}$ The framework described in this section is formally developed in KYLE BAGWELL \& ROBERT W. STAIGER, GATTTHINK (Nat'l Bureau of Econ. Research, Discussion Paper No. 8005, 2000); Kyle Bagwell \& Robert W. Staiger, An Economic Theory of GATT, 89 AM. ECON. REV. 215 (1999); Kyle Bagwell \& Robert W. Staiger, Domestic Policies, National Sovereignty and International Economic Institutions, 116 Q.J. ECON. 519 (2001); Kyle Bagwell \& Robert W. Staiger, The WTO as a Mechanism for Securing Market Access Property Rights: Implications for Global Labor and Environmental Issues, J. ECON. PERSP., Summer 2001, at 69.
} 
would then be absorbed by the exporting firms, which is to say that the export price they receive would be reduced. Government $B$, which cares about the profits earned by its exporters, thus experiences a cost when government $A$ selects a higher import tariff. ${ }^{2}$ Since government $A$ does not internalize the full (i.e., worldwide) costs of a higher import tariff, it will set a tariff that is higher than would be efficient from a worldwide perspective, where efficiency is judged in relation to the objectives of governments $A$ and $B$. Of course, government $B$ views the situation in a symmetrical way, so that the governments in a world without a trade agreement have a problem: tariffs are too high.

Faced with this problem, the governments might seek a solution in the form of a trade agreement. A government would approach the negotiating table with the view that any cut in its own tariff (below its preferred unilateral rate) would be a concession. But it might be willing to make such a concession if the other government reciprocated with a concession of its own. In this way, the governments could undo some of the costs that their unilateral policies imposed on each other's exporters and thus arrive at a more efficient arrangement. Indeed, they could mutually gain only if they negotiated reciprocal reductions in their tariffs.

A trade agreement of this kind can succeed only if it includes scope for enforcement. At the negotiated tariff levels, all else being equal, each government would like to withdraw its concession and raise its tariff toward the preferred unilateral rate. But a government's temptation to withdraw a concession would be moderated if it believed that the other government would retaliate by withdrawing its own concession, as a withdrawal would induce movement back toward the unilateral outcome. In broad terms, then, negotiated concessions can be enforced if the trade agreement includes appropriate provisions for retaliation.

What we have described here is the "terms-of-trade" rationale for trade agreements. The central idea is that the import tariff of any one country reduces the terms of trade for its trading partners (i.e., the export price received by foreign exporters as compared to the export price received by the country's own exporters abroad) and thereby generates a negative pecuniary externality abroad. The consequence is a terms-of-trade-driven "Prisoners' Dilemma," in which tariffs are inefficiently high. While we have described this problem in simple terms, it turns out that in a very broad set of circumstances this is the underlying problem that a trade agreement might solve. We note that this theoretical perspective leads naturally to a discussion of terms like concessions, reciprocity, enforcement, and retaliation, which also appear in GATT/WTO parlance. Before pursuing this link further, however, we pause and briefly consider some common objections to this rationale.

\section{Objections to the Economic Rationale for Trade Agreements}

We consider here five objections to the terms-of-trade theory of trade agreements. In each case, we state the objection and then argue that it is misguided.

First, one could raise the question whether politics matter. In this vein, one could ask whether the terms-of-trade theory assumes that governments maximize national income. If so, the theory omits an important dimension, since real governments have important political motivations associated with the distribution of income.

In response to this objection, we point out that the terms-of-trade theory does not rely on the assumption that governments maximize national income. Nowhere in the above discussion is it assumed that governments are apolitical agents. We assume that a tariff hike by one government harms foreign exporters and thus the foreign government, but we allow that the foreign government may be concerned with the profits of its exporters for both economic and political reasons. Evidently, whether or not governments are politically motivated, a terms-of-trade driven Prisoners' Dilemma is the problem that a trade agreement can solve.

\footnotetext{
${ }^{2}$ Country $B$ 's consumers may gain from the lower price that a higher country $A$ tariff implies, but their economic gain will be small in comparison to the loss to country $B$ 's exporters.
} 
Second, one might also object that this approach is misguided since it is well-known that unilateral free trade is the optimal economic policy: something must be off here, because economists are always saying that this is indeed the case.

In response to this objection, we note that unilateral free trade can be optimal for a government, but only under restricted conditions: when the government maximizes national income and represents a small country. What does it mean that a country is small? If country $A$ is small, then a dollar increase in import tariff on good $\beta$ will lead to a dollar increase in the price of $\operatorname{good} \beta$ in country $A$. The full tariff is then "passed through" to the consumer and foreign exporters are not affected; there is no terms-of-trade externality. As small countries retain all of the benefits and costs of their tariff policies, the governments of such countries select their policies in an efficient manner even in unilateral settings. If these governments are national-income maximizers, then the efficient policies they select will correspond to unilateral free trade.

Third, one could further object that only a few countries are really large. Is it not true that only the very largest traders, like the United States and the European Union, can affect their terms of trade by their tariff choices?

In response to this objection, we note that it is really an empirical question, and that the studies made to date, which are summarized by Bagwell and Staiger, suggest that terms-oftrade externalities are common and significant. ${ }^{3}$ Here, we simply offer an intuitive response. If a country is truly small, exporters will be indifferent to the tariffs faced there, so that governments will have no incentive to dispute a small country's tariff policy. Yet we often see disputes between ostensibly small countries.

Fourth, one could also object that what is argued here sounds like the long-discredited idea of mercantilism.

In response to this objection, we note that a government is mercantilistic if it believes that (1) exports are good, regardless of the policy (higher domestic export subsidies, lower foreign import tariffs) that induces greater exports; and (2) imports are bad, regardless of the policy (lower domestic import tariffs, higher foreign export subsidies) that induces greater imports. By contrast, the terms-of-trade theory that we described above ascribes to each government a much more sophisticated outlook: (1) exports are good when additional exports are enjoyed as a consequence of a unilateral reduction in the foreign import tariff; (2) imports are bad when additional imports are experienced as a consequence of a unilateral reduction in the domestic import tariff; and (3) reciprocal increases in imports and exports can be good when they are achieved through reciprocal import tariff reductions.

Finally, one could object that it is economic nonsense to regard a unilateral tariff reduction as a concession. Does standard economic theory not say that unilateral liberalization is good?

In response to this objection, we note that standard economic theory says that any unilateral change (up or down) from a government's unilaterally chosen tariffs is a "concession," if by concession one means a policy action that by itself is costly for a government to undertake. What the terms-of-trade theory says beyond this is twofold: starting from unilateral tariff choices, (1) only tariff concessions of the liberalizing variety can confer benefits on one's trading partners; and (2) provided that countries are large enough to affect their terms of trade with their unilateral tariff choices, the benefit conferred on each government from a (liberalizing) concession granted by its trading partners is greater than the cost incurred by each government in granting a reciprocal (equal trade volume) concession of its own. Hence, negotiated tariff concessions can produce mutual gains for governments only if (at least some) countries are large and the concessions entail (broadly) reciprocal tariff reductions.

\footnotetext{
${ }^{3}$ BAGWELL \& STAIGER, GATT-THINK, supra note 1.
} 


\section{Market Access in the GATT/WTO}

In general terms, the GATT/WTO offers a forum within which its member governments may negotiate over market access. Market access is interpreted in the GATT/WTO as reflecting the competitive relationship between imported and domestic products. For example, when government $A$ agrees to reduce an import tariff on $\operatorname{good} \beta$, it alters the competitive relationship between imported and domestic units of $\beta$ in favor of imported units and thus provides greater market access to foreign producers. Likewise, if government $A$ raises its import tariff on $\operatorname{good} \beta$, then the competitive relationship will be tilted in favor of domestic units, which implies diminished market access for foreign producers.

As we noted above, in GATT/WTO negotiations governments commonly view their tariff reductions as concessions whose cost is warranted only when an offsetting benefit is obtained from a reciprocal tariff concession by a trading partner. On a broad level, we can interpret the GATT/WTO legal structure as facilitating such mutually advantageous increases in the degree of market access.

Of course, if governments adopt this mind-set, a successful agreement must also provide rules that work to secure market access commitments. After all, government $A$ will not grant a reduction of its tariff in exchange for a tariff reduction by government $B$ if $A$ suspects that the corresponding access of its exporters to country $B$ 's market will not be secure. GATT rules play a role here, too. By proscribing certain forms of policy intervention (e.g., policies that discriminate against foreign products), the GATT provides governments with additional assurance that the tariff concessions they win from trading partners in negotiations will actually deliver the benefits they are after, namely, better market access for their exporting firms.

At the same time, governments are not held rigidly to their negotiated market access levels. For example, they may renegotiate their market access commitments, provided that they satisfy the explicit renegotiation provisions contained in GATT Article XXVIII. Under these provisions, a government may modify or withdraw a tariff concession, but in return it must offer compensating tariff concessions on other products or else accept equivalent withdrawals of concessions by its affected trading partners. Thus, governments are not held rigidly to the level of market access commitments implied by their negotiations. But they are held to the balance of market access commitments implied by their negotiations.

In broad terms, then, we may interpret GATT articles as (1) facilitating negotiations that lead to mutually advantageous increases in market access levels, and (2) creating a system of property rights over negotiated market access commitments that are secure against unilateral governmental infringement.

One may ask to what extent the above relates to the economic rationale for trade agreements. Consider, first, what happens when government $A$ lowers its import tariff on good $\beta$. Government $A$ then offers the exporters of country $B$ a gain in the level of market access in the following formal sense: country $A$ 's import demand curve is shifted outward, with the consequence that a greater volume of imports is demanded at any given price from country $B$ 's exporters. As a result of this shift, the exporters from country $B$ can expect to receive a higher export price. But that is simply to say that country $B$ receives a terms-of-trade gain when government $A$ reduces its import tariff.

Suppose next that government $A$ decides to renegotiate its tariff on good $\beta$ to a higher level. The resulting inward shift of country $A$ 's import demand curve implies a withdrawal of market access for country $B$ 's exporters, which can now expect to receive a lower export price. This amounts to a terms-of-trade loss for country $B$. But if as a result of these renegotiations government $B$ withdraws an equivalent amount of market access by raising its tariff on good $\alpha$ and inducing an equivalent inward shift of country $B$ 's import demand curve, then the balance of market access commitments between countries $A$ and $B$ will be preserved. Consequently, country $A$ 's exporters can expect to receive a lower export price as 
well, which is simply to say that the overall terms-of-trade change will be neutralized if government $B$ responds to government $A$ 's tariff hike with a reciprocal tariff increase of its own.

These examples point to a bridge between the terms-of-trade rationale for trade agreements and the market access emphasis found in the GATT/WTO. This bridge indicates that the terms-of-trade rationale for trade agreements and the market access emphasis found in the GATT/WTO are simply two different ways of saying the same thing. In general, a government that is concerned about the impact of a trading partner's market access restrictions on the prices received by its own exporters is concerned about the terms-of-trade effects of that trading partner's policies. The reduced export price (diminished terms of trade) is just the price effect induced by the corresponding reduction in export volume that restricted market access implies. And rules that prevent any government from unilaterally upsetting the balance of negotiated market access commitments equivalently prevent unilateral manipulation of the terms of trade. Therefore, the terms-of-trade logic can be completely recast in terms of market access concerns.

In accordance with this logic, we may conclude from the terms-of-trade theory that the fundamental problem to be solved by a trade agreement is insufficient market access. When a government imposes an import tariff, it does not internalize the harm that foreign exporters incur where this harm can be interpreted equivalently as a terms-of-trade loss or a restriction of market access, and unilateral policies therefore result in insufficient market access. This problem can be solved by a trade agreement that facilitates the exchange and security of greater market access commitments.

\section{Standards}

In the above framework, governments choose nothing but trade policies and the fundamental problem is insufficient market access. Does a further problem arise when governments choose standards? Assuming that standards choices do not create an international nonpecuniary externality, we now establish that the answer to this question is no. Insufficient market access remains the fundamental problem that a trade agreement may solve.

Let us extend the framework to include standards choices by supposing that government $A$ considers a reduction in the standards for its import-competing industry. This policy change would reduce the production costs of the import-competing firms in country $A$ in much the same way as granting a new or increased domestic production subsidy. Once again, there would be winners and losers in country $A$, and these trade-offs would be internalized by government $A$ in accordance with its own objectives. But the policy change would also affect exporters from country $B$. Facing tougher domestic competition, country $B$ 's exporters would obtain a lower export price, and country $B$ would thus experience a termsof-trade loss. Equally, country $B$ 's exporters would encounter diminished access to country $A$ 's market. As government $A$ would not internalize this cost, its preferred unilateral standards would fall to a lower than efficient level.

As this discussion confirms, the inefficiency of unilateral policies derives from one fundamental problem: each government sets its unilateral policies in a manner that delivers insufficient market access, since it fails to internalize the cost of diminished market access to its trading partner. This fundamental problem is then manifested through the unilateral determination of the various policy instruments, with import tariffs that are too high and/or standards in import-competing industries that are too low.

To put the point another way, suppose that government $A$ has made a market access commitment to government $B$ and that $A$ can fulfill its commitment by adopting any "policy mix" that it desires. For example, government $A$ could fulfill its commitment while setting standards at a low level in the import-competing industry if it also adopts low tariffs. Once the market access commitment is fulfilled, government $B$ does not have any (pecuniary) 
reason to concern itself with the particular policy mix that government $A$ uses. Government $A$ 's policies are relevant in government $B$ 's view only insofar as they affect the terms of trade and thus the overall access of country $B$ 's exporters to country $A$ 's market.

\section{Race to the Bottom and Regulatory Chill}

As the preceding discussion establishes, once an agreement secures an efficient market access commitment, no further problem remains: given a market access commitment, a government retains all of the costs and benefits of any adjustment in its policy mix, and an efficient policy mix is therefore selected. By contrast, the public debate about agreements on trade and standards policies centers on the perception of a "race-to-the-bottom" problem, in which governments face pressure to weaken their domestic labor and environmental standards for competitive effect in the international marketplace. This perception, in turn, has led to calls for agreements that would disallow standards below some minimal level, and that would thus prevent the adoption of low standards thought to fuel a race to the bottom. How, if at all, are race-to-the-bottom concerns interpreted in the framework developed above?

To begin to connect the framework with the public debate, we must consider the policy mix options that are actually available to governments. In particular, when governments expand market access through a GATT/WTO negotiation on tariff bindings, property rights over market access commitments are imperfect. First, while under GATT/WTO rules a government cannot respond to competitive pressures abroad by unilaterally restricting market access with an increase in its tariff (unless it is willing to pay compensation), the government may be tempted to restrict access by reducing standards in its import-competing industry. Second, if a government increases standards in its import-competing industry, this industry would be subjected to increased competitive pressure from abroad, but the government would not be allowed under GATT/WTO rules to raise its tariff (without compensation) and maintain its market access commitment. Consequently, the government might refrain from raising standards in an import-competing industry, since some of the benefits would flow to foreign exporters. Fundamentally, each of these described imperfections in property rights over market access commitments concerns the means at a government's disposal to respond to competitive pressures from abroad.

The first imperfection - that under GATT/WTO rules market access commitments are not secure against unilateral infringement by adjusting standards in import-competing industriescan lead to a race to the bottom, in which standards in import-competing industries are lowered. The second imperfection-that under GATT/WTO rules a government is not free to adjust its policy mix as it desires so long as it maintains its market access commitmentcan lead to a "regulatory chill," in which governments refrain from raising standards in import-competing industries. If GATT/WTO rules were enhanced to secure market access commitments against unilateral infringement through changes in trade or standards policies, while allowing each government to fulfill its market access commitment with the policy mix that it prefers, there would be no race-to-the-bottom or regulatory-chill problems of this nature.

The preceding discussion suggests a striking conclusion in light of the public debate: the true source of the race-to-the-bottom and regulatory-chill problems is not that low foreign standards generate competitive pressures that induce inefficiently low domestic standards; rather, the real source of these problems is the imperfections in property rights ${ }^{4}$ over market access commitments that arise when governments consider changing their own standards.

It may be objected, however, that we have developed this conclusion with reference only to standards choices in import-competing industries. Could it be that low standards levels in the foreign export industry give rise to competitive pressures that lead to inefficiently low

\footnotetext{
${ }^{4}$ We understand the term "property rights" over market access commitments to mean that a WTO member has a legal claim to request that the value of negotiated market access commitments be honored.
} 
standards in the domestic import-competing industry? Or could low standards levels in the foreign import-competing industry give rise to competitive pressures that lead to inefficiently low standards in the domestic export industry? Or even that low standards levels in the foreign export industry could lead to the choice of low standards in the domestic export industry as well, if exporters in both countries are competing for markets in a third country.

The answer to the first of the three questions raised above is no. Whether the competitive pressures that might lead the domestic government to set inefficiently low import-competing standards arise as a result of weak foreign export standards or strong foreign export technologies is irrelevant to the emergence of a race-to-the-bottom or regulatory-chill problem: as we observed above, what matters is the means that a government has at its disposal to respond to these competitive pressures, that is, whether or not property rights over market access commitments are imperfect.

The answer to the second question is also no. As in answer to the first question, the source of the competitive pressure does not bear on the existence of race-to-the-bottom or regulatory-chill problems. Again, what is relevant is whether or not property rights over market access commitments are imperfect. And in the case of export-industry standards, property rights imperfections will lead, if anything, to standards levels that are set too high. ${ }^{5}$

The answer to the third question raised above is more subtle. We thus extend the economic framework developed above to include competing export industries.

\section{Competing Export Industries}

Consider, then, a three-country framework, in which countries $B$ and $C$ export good $\beta$ to country $A$, while country $A$ exports good $\alpha$ to countries $B$ and $C$. As the strategic-trade literature has established, Governments $B$ and $C$ might each be tempted to use an export subsidy strategically so as to improve the competitive position of its own exporters. ${ }^{6}$ The end result could be a mutually destructive "subsidy war" that, ironically, would benefit only country $A$ 's consumers. Governments $B$ and $C$ might then seek an agreement in which they would lower (or even ban) export subsidies, with a view to restraining their destructive impulses. This is one way, for example, to interpret the GATT/WTO negotiations over the reduction of agricultural export subsidies. ${ }^{7}$

Suppose now that countries $B$ and $C$ succeed in forming an agreement that reduces (or prohibits) export subsidies. Then the same pattern might play out with standards: governments $B$ and $C$ might fall into a mutually destructive battle, as each relaxes (or at least resists increasing) the standards in its export industry in an attempt to improve the competitive position of its own exporters. Once again, in the end only country $A$ 's consumers would benefit. Governments $B$ and $C$ might thus seek an agreement to raise standards, again with the goal of restraining their destructive behavior.

In the three-country extension just described, externalities continue to run through the terms of trade. When government $B$ subsidizes its exporters or relaxes its export-industry standards, the price of good $\beta$ falls on the world market and the exporters from country $C$ experience diminished terms of trade. Equivalently, once exporters from country $B$ increase their production, exporters from country $C$ will find that their access to country $A$ 's market is diminished.

\footnotetext{
${ }^{5}$ The difference between this case and the first case raised above can be understood as follows. In the twocountry model, the terms-of-trade theory implies that, in the presence of imperfect property rights over market access commitments, governments distort their standards choices subsequent to tariff negotiations so as to frustrate the full liberalizing implications of their tariff commitments. In the particular case of export-industry standards, this consideration implies that, if anything, standards will be set too high relative to efficient levels.

${ }^{6}$ James Brander \& Barbara Spencer, Export Subsidies and Market Share Rivalry, 18 J. INT'L ECON. 83 (1985); Giovanni Maggi, Strategic Trade Policy with Endogenous Mode of Competition, 86 AM. ECON. REv. 237 (1996).

${ }^{7}$ Kyle Bagwell \& Robert W. Staiger, Strategic Trade, Competitive Industries and Agricultural Trade Disputes, 13 ECON. POL. 113 (2001).
} 
The three-country model gives rise to a novel interpretation of race-to-the-bottom and regulatory-chill problems. The choice of low export-industry standards in one country might encourage similar choices in other countries whose exporters compete for the same markets. From the perspective of the exporting governments, unilateral policy selection may thus lead to export-industry standards that are inefficiently low. This possibility is plausibly exacerbated when an agreement to restrain export subsidies is in place. Competing exporting governments may then gain from a further agreement to raise standards in export industries.

It bears emphasizing, however, that the welfare of importing governments would be reduced by such an agreement. In fact, the terms-of-trade theory suggests that such an agreement would diminish the ability of all the governments together to attain their individual objectives (i.e., such an agreement would be inefficient from a worldwide perspective in relation to the objectives of all the participating governments). The expansionary unilateral export policies that are selected by competing exporting governments engender a terms-oftrade gain for consumers in the importing country.

If their agreement induces exporting governments to internalize this gain, thus choosing efficient export policies from a worldwide perspective, they would in fact adopt export policies that are more expansionary than their unilateral choices, not less.

\section{Linking the Framework to the Public Debate}

In summary, our framework gives some credence to the race-to-the-bottom/regulatorychill fears emphasized in the public debate, but it does so in a limited and structured way that has important implications for the appropriate institutional response. According to our framework, in the absence of any nonpecuniary externality associated with the level of standards, two governments may face race-to-the-bottom or regulatory-chill problems that motivate them to negotiate standards for either of two reasons:

(1) Under GATT/WTO rules, property rights over market access commitments are imperfect. Standards in import-competing industries may thus be inefficiently low from the perspective of global government welfare.

(2) Governments with competing exporters may strategically lower standards with the goal of improving the competitive positions of their respective exporters. Standards in exporting industries may thus be inefficiently low from the perspective of the objectives of the exporting governments.

What is the appropriate institutional response? The first reason describes a legitimate standards problem: an agreement that eliminates this reason for low standards could benefit all governments. In this context, our framework suggests that the appropriate institutional response is to strengthen governments' property rights over negotiated market access commitments. By contrast, the second reason describes a standards problem that may be less legitimate: an agreement that eliminates this reason for low standards could represent an inefficient victory for exporting governments won at the expense of importing governments.

\section{General Approach}

We now propose a general approach based on the following guiding principles:

- governments can mutually benefit from negotiated policy changes that increase market access levels;

- negotiated market access commitments must be secure against unilateral government infringement where such infringement might derive from adjustments in tariffs or standards; and 
- governments should be free to satisfy their market access commitments by using whatever policy mix they desire.

To see the guiding principles in action, let us consider import policies. Under an agreement that respected these principles, governments could negotiate lower import tariffs and/ or higher import-competing standards so as to achieve efficient market access levels. Their respective market access commitments would also be secure: neither government could unilaterally infringe its commitment, by adjusting its import tariff upward and/or its importcompeting standard downward. At the same time, a government would not be restricted from adjusting the policy mix to maintain its market access commitment. Such adjustments would not have an impact on foreign exporters. Since the costs and benefits of such an adjustment would reside entirely within domestic borders, a government would pursue such an adjustment only if it were (internally) efficient.

This approach facilitates a negotiated movement toward greater market access through lower tariffs and/or higher import-competing standards. Importantly, this movement can be made even if direct negotiations concern tariffs alone. Given any initial standards, the governments can negotiate tariffs that would achieve the desired level of market access. Subsequent to this negotiation, if a government seeks to lower its standards from the initial level, it can, provided that it also lowers its import tariff so as to maintain its market access commitment. Similarly, if a government then seeks to increase its standards, it would be permitted to raise its import tariff and thus maintain its market access commitment. In this way, once negotiated market access levels are determined, each government can reconfigure its policy mix to fulfill its market access commitment in the preferred manner.

This approach also has implications for export policy. Suppose that a government would like to raise standards in its export industry but is concerned that its exporters would then be at a competitive disadvantage relative to competing foreign exporters. In short, the government fears that increasing domestic standards would reduce its exporters' access to the importing country's market. Under our approach, the government would not face this fear: it would be allowed to raise its standards and at the same time increase its export subsidy, so that the market access of its exporters would not be altered (in either direction). This approach ensures that the adjustment in the export policy mix will not affect the export price, guaranteeing that the full costs and benefits of the adjustment are retained within national borders. Consequently, under this approach a government will choose its export-industry policy mix in an (internally) efficient manner.

\section{Cross-Country Linkage}

The general approach described above draws linkages between the trade and standards policies within the same country. The theoretical framework suggests that such internal linkages are sufficient. This perspective also resonates nicely with the notion of national sovereignty: in essence, each government is allowed to do as it pleases, so long as its policy changes do not violate its negotiated market access commitments.

At a practical level, however, the proposed internal linkages may not always be feasible. First of all, export policies are already heavily restrained under GATT/WTO rules. In the current legal environment, therefore, a government may have insufficient flexibility to counterbalance the export-price effects of changes in its export-industry standards. A second reason why internal linkages may not be feasible, which is especially significant for some developing countries, is that an exporting government may be unable to finance a significant export-subsidization policy. If a government's ability to use export subsidies is constrained for these (or other) reasons, it may not be able to increase export-industry standards while maintaining its exporters' access to the importing country's market. Exportindustry standards could then become frozen at inefficiently low levels. 
If such constraints are unavoidable, cross-country linkages might be considered. For example, higher export-industry standards in one country could be linked with lower import tariffs in another. This linkage might offer a feasible means of raising export-industry standards while preserving exporters' access to the importing-country market.

At the same time, it should be understood that cross-country linkages raise new difficulties. Notably, cross-country policy adjustments that maintain market access (and thus the terms of trade) may exert a pecuniary effect on the welfare of the importing government. Such adjustments introduce a local-price externality: by altering its tariff, the importing government generates a different local (consumption) price for the imported good. There is no guarantee that the local-price change will be beneficial to the importing government, or that the change in standards is attractive to the exporting government. Thus, the negotiating environment of cross-country linkages is complex and the identification of a simple set of guiding principles that can confidently be expected to promote efficient policies becomes more difficult.

With the economic framework now in hand, we proceed in part II to make specific proposals that implement the general approach described above for internal linkages. We postpone a full discussion of cross-country linkages until part III, where we broaden our framework and consider nonpecuniary externalities. The presence of such externalities further motivates consideration of cross-country linkages, and we offer specific proposals for cross-country linkages in that part.

\section{LABOR AND THE ENVIRONMENT: PEGUNIARY EXTERNALITIES}

\section{The Race to the Bottom: Nonviolation Complaints}

Does the WTO contract, as it now stands, encompass legal instruments that ensure that a race to the bottom with respect to standards will not take place? As we stated above, such a risk is not simply imaginary: some WTO members might have an incentive to lower their standards.

From the legal perspective, the answer runs as follows: the WTO contract does not contain any provisions that oblige the members to adopt any particular conduct with respect to standards. Hence, they are in principle free to raise or lower their standards. To the extent, however, that a change in the standards affects market access for foreign products, a WTO member might find itself the addressee of a nonviolation complaint. According to continuing GATT/WTO case law, nonviolation complaints are admissible when (1) a concession has been negotiated, and (2) a subsequent measure is adopted that (3) could not have reasonably been anticipated and that (4) reduces the value of the negotiated concession. ${ }^{8}$

What is crucial is point (2): the subsequent measure can be perfectly legal. Still, the WTO member responsible for such a measure is obliged to respond to the allegation that its action resulted in reducing the value of the negotiated concession.

The rationale for nonviolation complaints may be understood in terms of the need to make negotiated market access commitments secure against unilateral infringement, with the knowledge that such infringement could occur through legal changes in any of various measures. A WTO member has a greater incentive to offer the concession of access to its own market when it is confident that its negotiated access to its trading partner's market is secure. When market access commitments are made more secure, therefore, the potential for liberalization is enhanced.

Throughout the GATT years, the subsequent measure involved, in all but one case, the granting of a subsidy to a domestic producer that led to import substitution. In the WTO

\footnotetext{
${ }^{8}$ See, e.g., European Communities-Payments and Subsidies Paid to Processors and Producers of Oilseeds and Related Animal-Feed Proteins, Jan. 25, 1990, GATT B.I.S.D. (37th Supp.) at 86, 128-29 (1991).
} 
era, the notorious Kodak-Fuji litigation made it clear that regulatory subsidies can be the object of a nonviolation complaint. ${ }^{9}$ At the same time, that very Kodak-Fuji panel report held for the proposition that nonviolation complaints are truly exceptional legal instruments that should not be used lightly; otherwise, WTO adjudicating bodies might end up pronouncing on any regulatory intervention that might have indirect market access incidence. Does this holding still prevail? Most likely, not. In the recent Asbestos report, the Appellate Body held for the position that a nonviolation complaint can have a health-based measure with a trade incidence as its subject matter. ${ }^{10}$

A possible argument against this position might run as follows. It is difficult to maintain that countries will not enforce health measures when appropriate. Public health (albeit with variations) is a truly universal value. Because of its universal character, one can hardly imagine that WTO members would claim that they could not anticipate that a trading partner would block exports to its market for health reasons. Therefore, nonviolation complaints against health-based measures can never satisfy the "reasonable expectations" requirement, since it is unreasonable to expect that WTO members will not adopt health measures that conform with the WTO contract when and where warranted. ${ }^{11}$ However, an argument along these lines was dismissed by the Appellate Body in the Asbestos case. ${ }^{12}$

We can reasonably conclude that, if a nonviolation complaint is feasible against a healthbased measure with trade incidence, it could well be feasible as regards "relaxation" of labor and environmental standards. In fact, at least in the case of labor standards, the impact on the value of the concession will in all likelihood be more immediate: unlike health-based measures, which have to be nondiscriminatory (that is, applicable to both domestic and foreign products), a relaxation of labor standards will by definition confer an advantage on domestic products only.

This is not the end of the story, though. The remedy when a nonviolation complaint succeeds is that a WTO adjudicating body will recommend a "mutually satisfactory adjustment."13 Exactly what a "mutually satisfactory adjustment" amounts to is hard to say. There is no positive case law in this respect. Yet as Article 26.1(b) of the Understanding on Rules and Procedures Governing the Settlement of Disputes ${ }^{14}$ makes clear, a "mutually satisfactory adjustment" does not involve the obligation to withdraw the challenged measure. It could

\footnotetext{
${ }^{9}$ See Japan-Measures Affecting Consumer Photographic Film and Paper, WTO Doc. WT/DS44/R (Mar. 31, 1998). In this case, the panel did not reject the U.S. complaint, which was directed, inter alia, against lax enforcement of Japanese competition laws. Thus, in principle, it accepted that such an allegation can constitute a nonviolation complaint if, of course, the value of negotiated market access commitments is reduced as a result of lax enforcement of antitrust laws.

${ }^{10}$ See European Communities-Measures Affecting Asbestos and Asbestos-Containing Products, WTO Doc. WT/DS135/AB/R, paras. 182-97 (Mar. 12, 2001) [hereinafter Asbestos Report]

${ }^{11}$ WTO members might attempt a different approach: it might be claimed that the circumstances at hand do not present a legitimate health-based reason for blocking trade. But with such an approach, they will be arguing that their trading partner's decision to block trade on health grounds violates the WTO contract. The condition to move to a nonviolation complaint is precisely that no violation of the WTO contract has occurred.

${ }^{12}$ Paragraph 188 of the Asbestos Report, supra note 10, reads:
}

The European Communities also contends that the Panel erred in finding that Article XXIII:1(b) applies to measures which pursue health, rather than commercial, objectives and which can, therefore, be justified under Article XX(b) of the GATT 1994. Once again, we look to the text of Article XXIII:1(b), which provides that "the application by another Member of any measure" may give rise to a cause of action under that provision. The use of the word "any" suggests that measures of all types may give rise to such a cause of action. The text does not distinguish between, or exclude, certain types of measure. Clearly, therefore, the text of Article XXIII:1 (b) contradicts the European Communities' argument that certain types of measure, namely, those with health objectives, are excluded from the scope of application of Article XXIII:1(b).

${ }^{13}$ See Understanding on Rules and Procedures Governing the Settlement of Disputes, Art. 26.1 (b) [hereinafter DSU], in Marakesh Agreement Establishing the World Trade Organization, Apr. 15, 1994, Annex 2, in WORLD

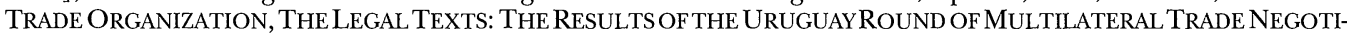
ATIONS 354 (1999).

${ }^{14}$ Supra note 13. 
hence be argued that nonviolation complaints do not per se constitute a credible threat against those WTO members that might have an incentive to lower their standards.

This does not mean, however, that the use of nonviolation complaints should be discouraged. Active use of this instrument automatically leads to enhanced transparency with regard to the domestic policy choices. Moreover, a "mutually satisfactory adjustment" can occasionally prove to be a powerful weapon in itself: some WTO members will have to ponder whether lowering their standards is really worth it if they have to face higher entry barriers in their export markets as a result. The compensation they will have to pay (higher entry barriers) might remove much of the incentive to relax their standards. Indeed, if the prospect of this compensation works to secure market access commitments against unilateral government infringement, it will prevent the race-to-the-bottom problem from arising. To conclude, in practice nonviolation complaints can prove to be a useful instrument from this perspective.

So far we have addressed the usefulness of nonviolation complaints as an instrument to discourage a race to the bottom in a purely bilateral scenario. Nonviolation complaints can play a role in the competing-exporters scenario as well: imagine that countries $A$ and $B$ export to country $C$ and that all three countries are WTO members. If country $B$ were to lower its standards, then the volume of exports from country $A$ to country $C$ would be reduced (or even eliminated). In this case, country $C$ is not competing in the product market at hand and so in all likelihood would welcome the reduction in country $B$ 's standards. And, as we discussed above, the government of country $B$ might indeed gain from this reduction.

In such a case, country $A$ can challenge country $B$ 's actions through recourse to a nonviolation complaint. ${ }^{15}$ Indeed, in the case where country $C$ does not compete in the product market at hand, a nonviolation complaint by country $A$ against country $B$ is all there is to avoid a race to the bottom. At the same time, it should be recalled that the legitimacy of the standards problem is less clear in the competing-export scenario, since an increase in exportindustry standards would then harm country $C$.

On the basis of this discussion and the general approach described in the previous part, we propose that an active role for nonviolation complaints be encouraged. ${ }^{16}$ An active role would help to secure market access commitments against unilateral government infringement through lower standards, and thus would work to guard against a race to the bottom while also facilitating greater incentives for trade liberalization.

\section{Regulatory Chill: Renegotiation}

Of course, a country could decide to raise its standards unilaterally. Unilateral behavior to this effect can be encouraged through a "creative" reading of GATT Article XXVIII. Normally, Article XXVIII (and the corresponding Article XXI of the General Agreement on Trade in Services) is invoked when a WTO member wants to modify its schedule of concessions (which reflects the agreed balance of concessions at the end of a trade round). But suppose a country requests Article XXVIII ${ }^{17}$ negotiations when it decides to raise standards

\footnotetext{
${ }^{15}$ A case like this has never been brought in WTO case law. Indeed, one might be tempted to argue that from a legal perspective such a case could never see the light of day. However, the wording of GATT Article XXIII.1(b) and, more specifically, the term "indirectly" reflected there suggest that such a possibility is not excluded a priori.

${ }^{16}$ We are well aware of the limits of this proposal. In the absence of ex officio complaints to this effect and a WTO ombudsman, the extent to which more nonviolation complaints will be brought against WTO members racing to the bottom will ultimately depend on the willingness of the leaders of the world community to punish such behavior. Subsidizing such complaints domestically is an option that deserves to be examined by national authorities. Anyway, at least the European Community and the United States, through the penetration of their private sector in almost all WTO markets and their strong public presence (embassies, etc.) all over the world, have the wherewithal to collect information in this context. All they need is the incentive to process the information and bring countries before the WTO.

${ }^{17}$ GATT Article XXVIII allows WTO members to rebalance the level of their commitments. Under Article XXVIII, whenever a WTO member wishes to increase its bound protection on an item, it must offer compensation on another item.
} 
in an import-competing industry. This country would in fact be requesting permission to raise its consolidated tariff protection in a particular sector. And instead of paying compensation by reducing its consolidated tariff protection in another sector (as normally happens under Article XXVIII of the GATT), the country in question would be "compensating" by raising its standards.

The spirit of this proposal is in line with the spirit of Article XXVIII, which in paragraph 2 pertinently states that " $[\mathrm{i}] \mathrm{n}$ such negotiations and agreement, ... the contracting parties concerned shall endeavour to maintain a general level of reciprocal and mutually advantageous concessions not less favourable to trade than that provided for in this Agreement prior to such negotiations." Imagine, for example, that Pooria, a WTO member, has bound its tariffs with respect to imports of wheat at 20 percent. As a result, 50 percent of wheat consumption in its market is satisfied by imports and 50 percent by domestic production. Pooria has no labor law at all, but it wants to become a good international citizen and decides to guarantee the core labor rights in its territory. A consulting firm advises Pooria that doing so would diminish its productivity, so that it would need to raise its duties for wheat to 28 percent to maintain the level of imports described above. What we propose here is that Pooria should be allowed to raise its duties in exchange for a promise to implement the agreed-upon labor standards without incurring any other obligation to make compensation.

Note that our proposal is applicable only when the government wishing to raise its standards does so with respect to an import-competing industry. If the government instead raised standards in an export industry, then its (importing) trading partners would experience a terms-of-trade loss: exports to those countries would be more expensive as a result of the cost-of-production increase entailed by an increase in standards. Thus, the trading partners would appropriately resist any compensation that this government might seek.

\section{Regulatory Chill: Renegotiation Plus}

The WTO could even provide an extra incentive to WTO members to raise their standards by making it explicit in GATT Article XXVIII that it can be used as a means to rebalance concessions against a rise in standards in import-competing industries. For example, one could add a new paragraph 6 to Article XXVIII that could read as follows:

If they so decide, WTO Members wishing to raise their labor standards and implement the standards reflected in ILO Conventions will be allowed to raise the level of their bound duties without incurring the obligation to compensate injured WTO Members. In case of disagreement as to the level of the increase, the dispute will be submitted to an arbitrator, who will decide on the level of increase within ... days.

Thus, the same level of market access would be preserved and the WTO member raising its labor standards would not be punished when doing so. Similar language could be added with regard to environmental standards.

Such an approach (an Article XXVIII plus) would naturally require a legislative amendment. The meeting in Qatar, however, signals the advent of a new round and such a proposal is therefore timely.

\section{LABOR AND THE ENVIRONMENT: NONPECUNIARY EXTERNALITIES}

As a general matter, nonpecuniary externalities arise whenever one party's decisions affect the welfare of another party through nonmarket channels. ${ }^{18}$ At the international level, nonpecuniary externalities can take many forms, ranging from global-commons issues to humanitarian concerns to international political spillovers.

\footnotetext{
${ }^{18}$ Of course, in many cases an action that generates a nonpecuniary externality carries implications for market access as well. In this part, we address actions that generate predominantly nonpecuniary externalities.
} 
For example, if the government of country $A$ were to adopt a lax environmental law regulating the output of chlorofluorocarbons, the government of country $B$ could have a legitimate concern about the resulting depletion of the ozone layer. Moreover, country $B$ 's concern could remain legitimate, even if country $A$ 's policy choice had no market access implications. Similarly, if country $A$ 's fishing fleets were depleting a species that country $B$ valued, then the government of country $B$ could have a legitimate concern about country $A$ 's regulation of its fishing fleets, even if direct market access issues were not involved.

Nonpecuniary externalities associated with labor standards might arise as well. The International Labour Organization refers to two broad issues under which nonpecuniary externalities could create a problem with the unilateral choice of labor standards that might be solved through international negotiation. First, country $A$ 's weak labor standards may provoke "humanitarian" concerns in country $B$, if the government of country $B$ has a direct concern for the well-being of workers in country $A$. And second, weak labor standards and poor social conditions in country $A$ may contribute, in the words of the preamble to the ILO Constitution, to social "unrest so great that the peace and harmony of the world are imperilled," and thus give rise to "political" concerns in country $B$.

Importantly, the solutions we have proposed above to handle the market access problems associated with labor and environmental standards do not suffice to solve a problem that arises instead as a result of a nonpecuniary externality. Hence, the generation of important nonpecuniary externalities associated with labor and environmental standards requires additional consideration as to the possible involvement of the WTO.

To see the distinction between these two kinds of problems, suppose that country $A$ chooses to stop enforcing its minimum wage policy in an import-competing industry. Suppose further that the government of country $B$ is concerned about the change in country $A$ 's policy because of the pecuniary implications of this choice. In particular, country $B$ may be worried about the implications of this policy for its exporting firms. If as a result of this concern country $A$ is led to make an inefficient unilateral choice, then our discussion above suggests that a possible solution might entail agreement by the government of country $A$ to mitigate the market access implications of its minimum wage decision, perhaps by accompanying this change in its labor standards with a reduction in its import tariff. That step would insulate the economic well-being of country $B$ 's citizens from country $A$ 's policy decisions and eliminate the international externality that accounted for the inefficiency of country $A$ 's unilateral choice of labor standards, while preserving for the government of country $A$ a degree of sovereignty over its choice of those standards.

Such a solution, however, which focuses on the market access implications of country $A$ 's labor standards choices, would be ineffective if the government of country $B$ were concerned instead about the implications of country A's change in policy for the welfare of country A's workers and its humanitarian/political ramifications. In this case, if international efficiency is to be achieved, a more invasive solution would have to be sought, whereby the government of country $B$ would be given a voice in country $A$ 's decision about whether to scrap its minimum wage laws. In particular, it would no longer do simply to provide country $B$ with assurances that decisions made by country $A$ 's government would have no important market access implications.

Finally, if both elements of country $B$ 's concern were present in this example, it might make sense to seek "targeted" solutions, which would address the first concern with market access agreements and the second with more invasive agreements. A central question then becomes: To what extent should the WTO become involved in addressing problems associated with labor and environmental standards that arise as a result of nonpecuniary externalities? 


\section{Possible Involvement of the WTO}

In principle, the WTO could become involved at either or both of two distinct levels in addressing problems associated with labor and environmental standards that arise as a result of nonpecuniary externalities. First, solutions could be sought through WTO negotiations; and second, solutions could be enforced by WTO dispute settlement procedures, whether or not these solutions were negotiated in the WTO.

The possibility that distinct issues-in this case, market access issues and nonmarket access issues-might be usefully combined in a single negotiating forum depends in part on the instruments available to the parties for distributing the gains created by their negotiations. ${ }^{19}$ The possibility that distinct issues might be gainfully linked for enforcement purposes depends in part on whether these issues are viewed as complements (the value of attaining agreement on one issue rises when agreement on the other issue is reached) or substitutes (the value of attaining agreement on one issue falls when agreement on the other issue is reached) in the objectives of governments. ${ }^{20}$ In short, as we discuss below, whether or not it is advisable to negotiate and/or enforce solutions to problems that arise from nonpecuniary externalities within the WTO will depend on the circumstances.

\section{Negotiations in the WTO}

Should nonmarket access issues associated with labor and environmental standards be negotiated in the WTO? Put differently, should agreements on labor and environmental standards be negotiated in the WTO to address problems that arise as a result of nonpecuniary externalities associated with unilateral standards choices?

In principle, a case can be made for combining these issues in a single negotiating forum, if it enhances the negotiating parties' flexibility in dividing the gains created by their negotiations. ${ }^{21}$ For example, suppose country $A$ pollutes a stream that flows across the border into country $B$. A negotiation between the governments of countries $A$ and $B$ that focused too narrowly on water standards might fail, if as a consequence the government of country $B$ had nothing to offer country $A$ in return for $A$ 's tighter pollution controls. If, on the other hand, country $B$ could offer country $A$ a market access concession in return for $A$ 's tighter standards, then negotiations might result in an efficient resolution of the problem.

The key question is, Does country $B$ need to be able to offer country $A$ a WTO binding to induce the government of country $A$ to raise its water pollution standards to an efficient level? There are two reasons why the answer to this question may be no.

First, the notion that market access concessions are the only thing of value that governments can offer in negotiations seems overly restrictive. For example, the 1980 s witnessed international "debt for environment" swaps between the developed and the developing countries, and more generally most developed countries give direct financial aid to many developing countries and often tie this aid to certain conditions. Hence, the ability to find alternatives to market access concessions when dividing the gains from international negotiations among the parties to them seems fairly widespread.

Second, even if one country wishes to offer market access to another in return for strengthening the other's standards, there is no particular reason why this offer must take the form of a WTO binding. For example, the government could offer to set its applied (most-favorednation) tariff below the bound rate in exchange for tighter standards abroad. Such a bargain

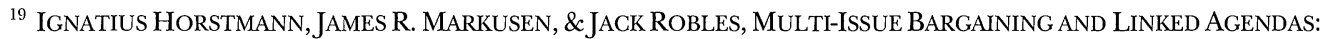
RICARDO REVISITED OR No PAIN No GAIN (Nat'l Bureau of Econ. Research, Working Paper No. 8347, 2001).

${ }^{20}$ Giancarlo Spagnolo, Issue Linkage, Delegation, and International Policy Cooperation (2001) (unpublished manuscript, on file with Stockholm School of Economics).

${ }^{21}$ Horstmann, Markusen, \& Robles, supra note 19.
} 
does not require WTO involvement. Alternatively, in exchange for one country's promise to strengthen its standards, its trading partners might indicate willingness to engage in future market access negotiations in the WTO on products important to that country's exporters. In a bargain that took this form, there again would be no explicit link between standards levels and WTO bindings, and no need for the WTO to be involved in such a bargain.

If we focus on the most currently relevant case, that of developed countries seeking to raise labor and environmental standards in developing countries, an additional possibility is introduced by the Enabling Clause and the Generalized System of Preferences (GSP). This option enables a developed country to condition the promise of additional preferential market access on the standards of the developing country. ${ }^{22}$

What exactly are the Enabling Clause and the GSP? In a 1971 decision, the GATT Contracting Parties agreed that "the provisions of Article I shall be waived for a period of ten years to the extent necessary to permit developed contracting parties . . . to accord preferential tariff treatment to products originating in developing countries ... without according such treatment to like products of other contracting parties."23

Subsequently, in 1979, the GATT Contracting Parties decided that "[n] otwithstanding the provisions of Article I of the General Agreement, contracting parties may accord differential and more favourable treatment to developing countries, without according such treatment to other contracting parties." ${ }^{24}$

This decision, known as the Enabling Clause, allows developed nations that are members of the GATT to apply "[p]referential tariff treatment ... to products originating in developing countries in accordance with the Generalized System of Preferences." ${ }^{25}$

National GSP lists are not always transparent: the identity of enlisted developing nations and the extent of commitments depend largely on political considerations. Arguably, the consistency of some national GSP lists with the principle of nondiscrimination is subject to question. Developing countries, however, have refrained from challenging national GSP schemes that could arguably contravene the letter and spirit of the Enabling Clause, because in most instances they have little incentive to do so; they would rather be on good terms with GSP donors and profit from the eventual extension of a GSP to them.

Recently, Brazil threatened legal action for the first time with respect to practices of the European Community (EC) that allegedly were inconsistent with the Enabling Clause. Had Brazil persisted, this would have been a WTO adjudicating body's first opportunity to dwell on these issues. Brazil's request for consultations with the European Community, though, was not followed by a request for the establishment of a panel. ${ }^{26}$ Since there has been no notification of a solution reached by the parties, ${ }^{27}$ one can only speculate as to what actually persuaded Brazil to discontinue its original request.

The justiciability of GSP-related concerns aside, the new generation of GSP lists does link preferences to labor standards. For example, the European Community's GSP list ${ }^{28}$ contains

\footnotetext{
${ }^{22} \mathrm{~A}$ similar possibility is to condition membership in free trade agreements or customs unions on the strength of standards (along the lines of the recently negotiated U.S.-Jordan Free Trade Agreement). A potential risk should be noted, though: if governments see preferential arrangements as the only feasible way to address standards concerns, then the result may be a proliferation of tariff discrimination, with the possibility of associated damage to the WTO system.

${ }^{23}$ Generalized System of Preferences, June 25, 1971, GATT B.I.S.D. (18th Supp.) at 24, 25 (1972).

${ }^{24}$ Differential and More Favourable Treatment, Reciprocity and Fuller Participation of Developing Countries, Nov. 28, 1979, id. (26th Supp.) at 203, 203 (1980) (citation omitted).

${ }^{25} I d$. (citation omitted).

${ }^{26}$ See European Communities-Measures Affecting Soluble Coffee, Request for Consultations by Brazil, WTO Doc. WT/DS209/1 (Oct. 19, 2000).

${ }^{27}$ Which should have been given in accordance with Article 3.6 of the DSU, supra note 13.

${ }^{28}$ National GSP lists are available online at the Web site of the UNCTAD, <http:www.unctad.org $>$.
} 
special incentive arrangements that operate on the basis of an additional preferential margin, which is granted to beneficiary countries that comply with certain requirements related only to labor standards and environmental protection. The labor standards whose adherence the European Community compensates are those reflected in ILO Conventions Nos. 87, 98, and $138 ; ;^{29}$ that is, those on the right to organize and bargain collectively and child labor. The United States imposes similar conditions for accession to its GSP list. ${ }^{30}$

In practice, the institutional arrangement just described can operate either when a new round is being negotiated or later. In the first scenario, at the end of the negotiations developed nations could offer additional market access opportunities to developing countries in exchange for strengthened labor or environmental standards. Conversely, developed nations could make a precommitment that they would add developing nations willing to raise their labor standards at any time to their GSPs.

An advantage of a GSP-based approach is its flexibility. A disadvantage is the lack of legal security: GSP beneficiaries can enter and leave GSP lists without any motivation. The effectiveness of this approach will depend on the willingness of donor countries to take their GSP commitments seriously. ${ }^{31}$

In sum, if these or other approaches are feasible, so that one country does not need to offer another country a WTO binding to induce that country to tighten its standards, then agreements on labor and environmental standards need not be negotiated in the WTO to address problems that arise as a result of nonpecuniary externalities associated with unilateral standards choices. A GSP-based approach is, of course, nonbinding in nature, hence hardly enforceable. It does, however, provide parties interested in high labor standards with an incentive-compatible structure, since they will in fact be compensating WTO members willing to conform to their standards.

\section{Enforcement in the WTO}

Should agreements on labor and environmental standards negotiated outside the WTO to address problems that arise as a result of nonpecuniary externalities associated with unilateral standards choices be enforced by means of WTO dispute settlement procedures? Would it be wise for the WTO to utilize its scarce enforcement power to prevent race-to-thebottom/regulatory-chill problems from occurring?

The problem of enforcement of WTO commitments can be boiled down to the task of holding each country's market access commitments to a manageable level, so that no country has an incentive to break those commitments. ${ }^{32}$ In principle, it is therefore never a good idea for the WTO to focus on some ways that countries could break their market access commitments (e.g., by a unilateral increase in tariffs) to the exclusion of others (e.g., by a unilateral weakening of a labor or environmental standard).

${ }^{29}$ ILO Convention (No. 87) Concerning the Right to Organize and to Bargain Collectively, July 9, 1948, 68 UNTS 17; ILO Convention (No. 98) Concerning Freedom of Association and Protection of the Right to Organize, July 1, 1949, 96 UNTS 257; ILO Convention (No. 138) Concerning Minimum Age for Admission to Employment, June 26, 1973, 1015 UNTS 297.

${ }^{30} 19$ U.S.C. $\$ \S 2461-2467$ (1994).

${ }^{31}$ If this lack of legal security is determined to be an impediment to the use of GSP for this purpose, it might be possible to enhance the legal security of GSP commitments by allowing each developed country to record a list of criteria for GSP benefits in its Article II schedule.

${ }^{32}$ For an economic perspective on enforcement in trade agreements, see BAGWELL \& STAIGER, GATT-THINK, supra note 1; Kyle Bagwell \& Robert W. Staiger, A Theory of Managed Trade, 80 AM. EcON. REV. 779 (1990); Avinash Dixit, Strategic Aspects of Trade Policy, in ADVANCES IN ECONOMIC THEORY: FIFTH WORLD CONGRESS 329 (Truman F. Bewley ed., 1987); Giovanni Maggi, The Role of Multilateral Institutions in International Trade Cooperation, 89 AM. ECON. REV. 190 (1999). 
Economic theory points to circumstances in which explicit linkage between the WTO and, say, the ILO, for enforcement purposes-whereby violation of ILO commitments would trigger retaliatory trade measures authorized by the WTO (and possibly vice versa) - may be beneficial, and also circumstances in which such linkage provides no benefits or might even be harmful. ${ }^{33}$ Explicit linkage of this kind could simply lead to a reallocation of enforcement power across WTO and ILO agreements, in which case the effectiveness of the enforcement of WTO commitments might be diminished so as to enhance enforcement of ILO commitments. Alternatively, explicit linkage could lead to the creation of additional enforcement power that, in principle, could enhance the performance of each agreement. The outcome depends in part on whether these issues are viewed by governments as complements or substitutes. ${ }^{34}$ In short, the impacts of explicit linkage will depend on the circumstances.

Even with no linkage between the WTO and international labor organizations, however, countries can theoretically still threaten denial of market access as a means of enforcing commitments on labor standards negotiated in other international forums. For example, a developed country could threaten to revoke the GSP privileges it extends to a developing country if that country does not abide by the labor and environmental commitments negotiated between the two countries. Such a threat would not require WTO involvement. Alternatively, a developed country could threaten to raise to its bound level a tariff that had been applied below that level, if a developing country with which it had negotiated labor and environmental commitments does not abide by them. Again, no WTO involvement would be required.

Moreover, some linkage between the WTO and international labor and environmental organizations can occur even without the creation of any explicit links between the WTO and these organizations, and this "implicit" linkage in principle can always enhance the performance of each organization. Like the explicit linkage described above, the implicit linkage we are referring to involves the possibility that the WTO will authorize trade measures in the circumstance of, say, violation of an ILO commitment. But unlike explicit linkage, where the retaliatory trade measures would represent the use of new retaliation rights under augmented WTO rules, the trade measures under such implicit linkage would simply represent an exercise of already existing nonviolation nullification-or-impairment or renegotiation rights in the WTO.

Consider, for example, a country that has ratified an ILO convention and must therefore ensure that its labor policies are in line with this convention in order to conform with its ILO obligations. Suppose now that this country binds its tariffs in WTO negotiations. If this country subsequently violates its ILO commitments by nonapplication of the ratified ILO convention, and if this nonapplication has market access implications-e.g., by reducing access to the country's markets from the level that its trading partners could have reasonably anticipated in light of its bound tariffs and ILO-conforming labor policies-then in principle its trading partners would have a right of redress under the DSU and GATT provisions on nonviolation nullification and impairment. Under this right of redress, either the country would have to find a way to restore the original level of market access, or else its trading partners could be authorized under WTO rules to seek compensation for the nullification

\footnotetext{
${ }^{33}$ Recent papers on the topic of linkage and trade agreements include Paola Conconi \& Carlo Perroni, Issue Linkage and Issue Tie-in in Multilateral Negotiations, $4 \mathrm{~J}$. INT'L ECON. (forthcoming); Josh Ederington, International Coordination of Trade and Domestic Policies, 91 AM. ECON. REv. 1580 (2001); Josh Ederington, Global Environmental Agreements and Trade Sanctions (May 2001) (unpublished manuscript); Nuno Limão, Trade Policy, Cross-Border Externalities and Lobbies: Do Linked Agreements Enforce More Cooperative Outcomes? (2000) (unpublished manuscript, on file with Department of Economics, Columbia University); Spagnolo, supra note 20.

${ }^{34}$ See text at note 20 supra.
} 
or impairment of their market access rights (which could include reciprocal withdrawals of market access, i.e., tariff increases that affect this county's exports). The key point is that ratification of ILO commitments can create "reasonable expectations" for trading partners that a country will apply these conventions, and nonapplication of these conventions may then subject the country to the possibility of nonviolation complaints in the WTO.

While we have described a role for the WTO Agreements' nonviolation nullification-orimpairment provisions in helping to enforce ILO commitments, the renegotiation provisions of the WTO can play a similar role in principle. ${ }^{35}$ In both instances, the point is the same: existing market access rights in the WTO might be used to help enforce commitments to labor standards negotiated in the ILO, if violation of ILO commitments would imply important market access consequences and thus set the stage for a nonviolation complaint within the WTO or trigger WTO renegotiations.

In this general way, "implicit" linkages between WTO and ILO commitments-implicit since a violation of an ILO commitment would not be considered a violation of WTO commitments-can play a useful role in contributing to the enforcement of ILO commitments. The same would apply to commitments negotiated in any other international labor or environmental organization. And, at the same time, the legitimate exercise of these links may be an important component of enforcing WTO commitments and maintaining the balance between rights and obligations for WTO member governments.

\section{Proposal}

The possibility of gainfully combining market access and nonmarket access issues in a single negotiating forum depends in part on the instruments available to the parties for distributing the gains created by their negotiations. And the possibility of gainfully linking distinct issues for enforcement purposes depends in part on whether these issues are complements or substitutes in the objectives of governments.

In short, whether or not it is advisable to negotiate and/or enforce solutions to problems that arise from nonpecuniary externalities within the WTO depends on the circumstances. The only exception seems to be with regard to implicit enforcement links between the WTO and labor and environmental agreements negotiated elsewhere. These implicit enforcement links represent an exercise of already existing nonviolation nullification-or-impairment or renegotiation rights in the WTO, and the legitimate exercise of these links can be an important component of enforcing WTO commitments and maintaining the balance between rights and obligations for WTO member governments.

These considerations suggest the following proposal with regard to the role of the WTO in addressing nonpecuniary externalities associated with labor and environmental standards:

(1) as a general matter, agreements on labor and environmental standards should not be negotiated in the WTO to address problems that arise as a result of nonpecuniary externalities associated with unilateral standards choices; and

(2) as a general matter, explicit links between the WTO and other international labor and environmental organizations should not be established for enforcement purposes, but the existing implicit enforcement links between the WTO and other organizations-as embodied in the nonviolation nullification-or-impairment and renegotiation provisions of the WTO Agreements—should be encouraged.

\footnotetext{
${ }^{35}$ The WTO Agreements' renegotiation provisions might come into play if a country's nonconformity with its ILO obligations were responsible for enhanced export volumes that its trading partners did not wish to accept.
} 


\section{The Need to Micromanage Divergent Public Orders}

The WTO confronts a complex set of questions associated with labor and environmental standards. We argue above, however, that progress can be made if the market access issues associated with these questions are separated from the nonmarket access issues. We identify race-to-the-bottom and regulatory-chill concerns as market access issues, we suggest that the WTO should address these concerns, and we describe ways that WTO principles and procedures might be augmented to do so. As for nonmarket access issues, we argue that as a general matter these are best handled outside the WTO, and that, while implicit links of the kind we describe above might be encouraged, explicit links between the WTO and other labor and environmental organizations should generally not be forged. We view these proposals as a measured approach to labor and the environment within the WTO.

Our approach is largely dictated by the uncertainty over linkages between trade and labor (or environmental, or any other public order) standards that permeates WTO law. Whether a WTO member can legitimately adopt laws that ban sales of goods produced according to unfair (in the mind of the regulating WTO member) labor standards is far from clear. Ultimately in the GATT context, the answer to this question will depend on the interpretation of "like products" and/or the term "public morals." With respect to the first term, we observe that the aforementioned recent Asbestos jurisprudence added only confusion to the preexisting discussion: as the report stands, whether or not protectionist intent matters for two products to be alike is difficult to state. If it does matter, it will be almost impossible to enact a law banning sales of products produced with unfair labor standards. If it does not, the opposite is probably true. By the same token, if the discussion shifts to the realm of GATT Article XX (assuming that protectionist intent is simply immaterial for the purposes of defining likeness), one would have to find a way to bring such laws under the ambit of the "public morals" exception. Steve Charnovitz ${ }^{36}$ has argued that this is indeed the case, but so far there is no WTO case law accepting this point of view.

A broad interpretation of the moral exception can open the door to a war between public orders: what is the WTO positive-law response, for example, to a complaint against a hypothetical EC law banning all imports from the United States as long as the latter continues to impose the death penalty, a sanction that does not correspond to the EC public order? This example might sound far-fetched, but there is already ample evidence that, on a smaller scale, some WTO members do link trade to conformity with their (not necessarily trade-related) public order: namely, the EC and U.S. GSP lists that we mentioned above; the United States-Jordan Free Trade Agreement, which contains references to labor standards; and a recent Belgian standard concerning labeling of products made in accordance with fair (to Belgian minds) labor standards.

These examples are the first indications of a growing need to micromanage regulatory diversity. Theoretically, micromanagement could be either self-policed or imposed in an exogenous manner. We do not believe that the first option is realistic; the current system of remedies ${ }^{37}$ in the WTO legal order gives more of an incentive to the greater players to impose their own public order (and, in fact, they have started doing so, albeit on a small scale so far, as the GSP lists, the Belgian standard, and the U.S.-Jordan Agreement mentioned above show).

An exogenous solution seems more appropriate. Such a solution could be legislative (though involving substantial costs) or simply the outcome of the interpretation of the existing WTO

\footnotetext{
${ }^{36}$ Steve Charnovitz, The Moral Exception in Trade Policy, 38 VA. J. INT'L L. 689 (1998).

${ }^{37}$ On this issue, see Petros C. Mavroidis, Remedies in the WTO Legal System: Between a Rock and a Hard Place, 11 EUR. J. INT'L L. 763 (2000).
} 
contract. Our proposal contains elements of both approaches but strongly favors judicial activity; by limiting linkages issues to addressing pecuniary externalities alone, the WTO dispute settlement system would stick to the idea of protecting market access and not be transformed into a court of general jurisdiction.

Our approach is probably consonant with the public international law concept of extraterritoriality. Amazingly, there has never been a discussion of this issue in WTO case law, although it has arisen on several occasions (the Tuna/Dolphin disputes probably being the most notorious). A WTO member wishing to request foreigners to respect its public order must demonstrate that it can legitimately legislate on the issue at hand. If an activity occurs beyond its frontiers but affects that WTO member, it will have to invoke the effects doctrine. The effects doctrine, at least in its version in the U.S. and EC legal orders, requests that the affected jurisdiction show substantial, foreseeable, and direct effects on the market. Even if the first two elements can be shown, the third criterion will be quite difficult to satisfy whenever a WTO member wishes to address a nonpecuniary externality. 